\title{
Lacrimal Gland Myoepithelial Cells Are Altered in a Mouse Model of Dry Eye Disease
}

Laura García-Posadas, ${ }^{* \dagger}$ Robin R. Hodges, ${ }^{* \dagger}$ Tor P. Utheim, ${ }^{* \dagger \ddagger \S}$ Ole Kristoffer Olstad, ${ }^{\S}$ Vanessa Delcroix, Helen P. Makarenkova, ${ }^{\top}$ and Darlene A. Dartt* ${ }^{* \dagger}$

From the Schepens Eye Research Institute/Massachusetts Eye and Ear* and the Department of Ophthalmology, ${ }^{\dagger}$ Harvard Medical School, Boston, Massachusetts; the Departments of Medical Biochemistry ${ }^{\ddagger}$ and Plastic and Reconstructive Surgery, ${ }^{\S}$ Oslo University Hospital, Oslo, Norway; and the Department of Molecular Medicine, The Scripps Research Institute, La Jolla, California

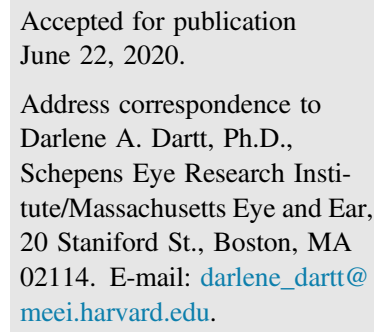

\begin{abstract}
The purpose of this study was to determine the pathogenic changes that occur in myoepithelial cells (MECs) from lacrimal glands of a mouse model of Sjögren syndrome. MECs were cultured from lacrimal glands of C57BL/6] [wild type (WT)] and thrombospondin 1 null (TSP1 ${ }^{-/}$, alias Thbs $1^{-/-}$) mice and from mice expressing $\alpha$-smooth muscle actin-green fluorescent protein that labels MECs. MECs were stimulated with cholinergic and $\alpha_{1}$-adrenergic agonists, vasoactive intestinal peptide (VIP), and the purinergic agonists ATP and UTP. Then intracellular $\left[\mathrm{Ca}^{2+}\right]$ was measured using fura-2, and contraction was observed using live cell imaging. Expression of purinergic receptors was determined by Western blot analysis, and mRNA expression was analyzed by microarray. The increase in intracellular $\left[\mathrm{Ca}^{2+}\right]_{\mathrm{I}}$ with VIP and UTP was significantly smaller in MECS from TSP1 ${ }^{-/-}$compared with WT mice. Cholinergic agonists, ATP, and UTP stimulated contraction in MECs, although contraction of MECs from TSP1 ${ }^{-1-}$ mice was reduced compared with WT mice. The amount of purinergic receptors P2Y1, P2Y11, and P2Y13 was significantly decreased in MECs from TSP1 ${ }^{-/-}$compared with WT mice, whereas several extracellular matrix and inflammation genes were up-regulated in MECs from $\mathrm{TSP}^{-/-}$mice. We conclude that lacrimal gland MEC function is altered by inflammation because the functions regulated by cholinergic agonists, VIP, and purinergic receptors are decreased in TSP1 ${ }^{-1-}$ compared with WT mice. (Am J Pathol 2020, 190: 2067-2079; https://doi.org/10.1016/j.ajpath.2020.06.013)
\end{abstract}

The lacrimal gland is a tubuloacinar gland responsible for secreting the aqueous part of the tear film. This secretion is neurally regulated and can be altered in pathologic states, such as dry eye disease and Sjögren syndrome. ${ }^{1}$ Afferent sensory nerves in the cornea and conjunctiva can be activated by different stimuli from the external environment; subsequently, these activated nerves stimulate efferent sympathetic (containing norepinephrine) and parasympathetic [containing acetylcholine and vasoactive intestinal peptide (VIP)] nerves that surround lacrimal gland cells. Release of these neurotransmitters stimulates lacrimal gland functions, most notably secretion of proteins, electrolytes, and water. ${ }^{1}$ In addition, lacrimal gland secretion can also be mediated by a nonadrenergic, noncholinergic pathway that includes activation of purinergic receptors $(\mathrm{P} 2 \mathrm{X}$ and $\mathrm{P} 2 \mathrm{Y}){ }^{2,3}$
The lacrimal gland is composed of three main cell types: acinar cells, ductal cells, and myoepithelial cells (MECs). ${ }^{4}$ Lacrimal gland MECs surround acini but not ducts. ${ }^{5}$ They have a stellate shape and multiple branching processes. The contractile function is possible based on the expression of $\alpha$-smooth muscle actin ( $\alpha$-SMA), which also serves as the main marker for all smooth muscle cells, including lacrimal gland MECs. ${ }^{6}$ MECs also express other smooth muscle markers, such as calponin and $\alpha$-actinin, ${ }^{7}$ and epithelial cell markers, such as cytokeratin 14 (CK14).

Supported by NIH NEI grant R01 EY026202 (H.P.M. and D.A.D.). Disclosures: None declared.

Current address of L.G.-P., IOBA, University of Valladolid, Valladolid, Spain. 
MECs are found in salivary, sweat, mammary, and lacrimal glands. ${ }^{5,7,8}$ In the mammary glands, they play an important role in milk ejection, by contracting in response to oxytocin. ${ }^{9,10}$ In the salivary gland, MECs play a role in contraction, basement membrane production, and tumor suppression. ${ }^{7}$ Despite longterm interest, the specific functions of MECs in the lacrimal gland have only recently been investigated. First, studies have found that progenitor cell markers, such as nestin, Musashi 1, p63, and ABCG2, co-localize with $\alpha$-SMA-positive cells in lacrimal glands, implying that MEC lineage contains progenitor cells and may play a role in regeneration and repair of the lacrimal gland. ${ }^{11,12}$ Second, two studies found the contractile capacity of lacrimal gland MECs. ${ }^{13,14}$ Using guinea pig lacrimal gland tissue pieces, Satoh et $\mathrm{al}^{14}$ found that MECs contracted in response to cholinergic, but not to adrenergic, agonists. Meanwhile, Hawley et $\mathrm{al}^{13}$ found that MEC contraction in response to oxytocin was impaired in lacrimal gland lobules from two mouse models of aqueous-deficient dry eye, nonobese diabetic mice, and MRL/lymphoproliferation mice compared with wild-type (WT) mice. Supporting an MEC functional response to neural agonists, lacrimal gland MECs express muscarinic, ${ }^{6}$ VIP,,${ }^{15}$ and purinergic receptors. ${ }^{3}$ Involvement of MEC purinergic receptors in intracellular $\mathrm{Ca}^{2+}$ responses of cultured MECs was reported, ${ }^{3}$ suggesting a potential role of MECs in tear secretion regulation. Thus, lacrimal gland MECs could play a role in both secretion and lacrimal gland repair.

Thrombospondin (TSP) 1 is a large matricellular protein that is found intracellularly and extracellularly. It has multiple domains, allowing it to support a large number of cellular functions, including cell migration, proliferation, and cell death, and to prevent inflammation. Although dry eye disease in humans has not been associated with TSP1 loss of function mutation, there is a polymorphism in TSP1 that predisposes individuals to develop dry eye after refractive surgery. ${ }^{16}$ Because corneal neural dysfunction is a critical component of dry eye in humans, corneal nerves are damaged in refractive surgery, and as corneal nerves are damaged in the TSP1 ${ }^{-1-}$ $\left(T h b s 1^{-1-}\right.$ ) mice, we feel that the TSP $1^{-l-}$ mouse model is a relevant model for a portion, although not all types of dry eye disease. ${ }^{17,18}$ In addition, in TSP1 null $\left(\mathrm{TSP}^{-/-}\right)$mice the appearance of inflammatory infiltrates corresponds to development of functional defects in the lacrimal gland, indicating its use as a model of dry eye disease. ${ }^{11,19,20}$ Moreover, in the lacrimal gland, TSP1 is highly expressed in $\mathrm{MECs}^{20}$ and that MEC function is strongly affected by the inflammation that occurs in these mice, ${ }^{13}$ suggesting a critical role of TSP1 in MEC function.

We hypothesize that inflammation that mimics dry eye spontaneously developed with age in $\mathrm{TSP}^{-1-}$ mice and alters MEC function regulated by neural agonists. ${ }^{20}$ The calcium dynamics and contractile capacity of lacrimal gland MECs isolated from the WT and TSP1 ${ }^{-l-}$ mice in response to parasympathetic and sympathetic neurotransmitters and purinergic agonists that can mediate lacrimal gland protein secretion were analyzed.

\section{Materials and Methods}

\section{Materials}

RPMI 1640 cell culture medium, penicillin/streptomycin, and L-glutamine were purchased from Lonza (Walkerville, IL). Fetal bovine serum was purchased from Atlanta Biologicals (Norcross, GA).

Antibodies used are listed in Table 1. VIP was from Anaspec (Fremont, CA), whereas fura-2/AM was from Invitrogen (Carlsbad, CA). The 35-mm glass-bottom culture dishes were from MatTek Corporation (Ashland, MA). Alamar blue was purchased from Thermo Fisher Scientific (Waltham, MA). TRIZOL, thapsigargin, carbachol ( $\mathrm{Cch})$, phenylephrine $(\mathrm{Ph})$, ATP, and UTP were from SigmaAldrich (St. Louis, MO).

\section{Animals}

All experiments were conducted following the ARVO Statement for the Use of Animals in Ophthalmic and Vision Research and were approved by the Schepens Eye Research Institute Animal Care and Use Committee. Male and female C57BL/6J mice with ages ranging from 4 to 12 weeks were purchased from Jackson Laboratories (Bar Harbor, ME) and used to optimize all protocols and to study normal lacrimal gland MEC function. C57BL/6J mice were then used as controls when compared with TSP1 $1^{-1-}$ mice.

$\mathrm{TSP}^{-1-}$ mice were originally obtained through Dr. J. Lawler (Beth Israel Deaconess Medical Center, Harvard Medical School, Boston, MA) and bred by Dr. Sharmila Masli (Boston University, Boston, MA). These mice were generated on the C57BL/6J background. Only female, 4- to 12-week-old $\mathrm{TSP} 1^{-l-}$ mice were used because of the higher prevalence of dry eye disease in females.

$\alpha$-SMA-green fluorescent protein (GFP) mice bred on a C57BL/6J background (3 male and 3 female) were a kind gift from Dr. Ivo Kalajzic (University of Connecticut, Storrs, $\mathrm{CT}$ ). In these mice, $\alpha$-SMA present in MECs is labeled with GFP, allowing for easy detection of MECs in culture.

All mice were euthanized with carbon dioxide for $5 \mathrm{mi}-$ nutes, followed by cervical dislocation as a secondary physical means to ensure animal death. Then, both exorbital lacrimal glands were excised.

\section{Culture of MECs}

MECs were cultured from mouse lacrimal glands using the following protocol: exorbital lacrimal glands from C57BL/6J, SMA-GFP, and TSP1 ${ }^{-1-}$ mice were isolated, minced into small pieces, and incubated at $37^{\circ} \mathrm{C}$ in collagenase III $(5 \mathrm{mg} / \mathrm{mL})$ dissolved in Krebs-Ringer Bicarbonate buffer $(\mathrm{KRB}, 120 \mathrm{mmol} / \mathrm{L} \mathrm{NaCl}, 25 \mathrm{mmol} / \mathrm{L}$ $\mathrm{NaHCO}_{3}, 10 \mathrm{mmol} / \mathrm{L}$ HEPES, $4.8 \mathrm{mmol} / \mathrm{L} \mathrm{KCl}, 1.2$ $\mathrm{mmol} / \mathrm{L} \mathrm{MgCl}_{2}, 1.2 \mathrm{mmol} / \mathrm{L} \mathrm{NaH}_{2} \mathrm{PO}_{4}$, and $1 \mathrm{mmol} / \mathrm{L}$ $\mathrm{CaCl}_{2}$ ) containing $0.5 \%$ bovine serum albumin (BSA) for 
Table 1 Sources of Antibodies

\begin{tabular}{|c|c|c|c|c|}
\hline Antibody & Supplier & Catalog no. & Dilution & Clone \\
\hline$\alpha-S M A$ & Diagnostic Biosystems, Pleasanton, CA & M0B001 & $1: 1000$ & $1 \mathrm{~A} 4$ \\
\hline$\alpha-S M A$ & Sigma-Aldrich, St. Louis, MO & A2547 & $1: 400$ & $1 \mathrm{~A} 4$ \\
\hline p63 & Santa Cruz Biotechnology, Dallas, TX & sc-25268 & $1: 200$ & D9 \\
\hline P63 & Abcam & Ab214790 & $1: 300$ & EPR5701 \\
\hline $\mathrm{P} 2 \times 3$ & Alomone Labs, Jerusalem, Israel & APR-026 & $1: 200$ & Polyclonal \\
\hline P2Y11 & Alomone Labs & APR-015 & $1: 200$ & Polyclonal \\
\hline P2Y13 & Alomone Labs & APR-017 & $1: 200$ & Polyclonal \\
\hline$\beta$-actin & Sigma-Aldrich & A2228 & $1: 1000$ & AC-74 \\
\hline
\end{tabular}

$\alpha$-SMA, $\alpha$-smooth muscle actin; CK14, cytokeratin 14; p63, tumor protein p63; P2X3, P2X7, P2Y1, P2Y11, and P2Y13, purinergic receptors.

three 10-minute cycles. The fragments were triturated between each cycle. After incubation, the fragments and cell suspension were filtered through a 50- $\mu$ m nylon mesh into a plastic centrifuge tube and centrifuged for 2 minutes at $500 \times g$. The pellet was washed twice with KRB buffer containing $4 \%$ BSA. The pellet was resuspended in KRB buffer plus $0.5 \% \mathrm{BSA}$, and cells were placed in culture dishes. Cells were fed with RPMI 1640 culture medium supplemented with $10 \%$ fetal bovine serum, $2 \mathrm{mmol} / \mathrm{L} \mathrm{L-}$ glutamine, $100 \mu \mathrm{g} / \mathrm{mL}$ of penicillin/streptomycin, $1 \% 1$ mol/L HEPES, nonessential amino acids mixture, and $1 \%$ sodium pyruvate. Cells were maintained for approximately 2 to 3 weeks in standard culture condition $\left(37^{\circ} \mathrm{C}\right.$, $5 \% \mathrm{CO}_{2}$ ), and medium was changed every other day. All experiments were performed with first passage cells that were grown for 1 day after trypsinization.

\section{Cell Characterization by Immunofluorescence Microscopy}

To confirm that the cultured cells were MECs, the expression of MEC markers $\alpha$-SMA and CK14, which in the lacrimal gland is only expressed in $\mathrm{MECs}^{21}$ (data not shown), were evaluated. The cell markers $\alpha$-SMA and CK14 in our cultured cells were regularly checked. During the optimization of the protocol, the expression of these markers at different time points between 2 and 28 days of culture was checked. For the remaining experiments, the cellular identity at the end of the primary culture period of 2 to 3 weeks was checked. Cells maintained their MEC markers throughout the entire period. The expression of p63, a progenitor cell marker, was analyzed. First-passage cultured cells were grown on 8-well multichamber slides and fixed in methanol. Slides with methanol-fixed lacrimal gland tissue sections were used as controls. Cells were incubated for 1 hour with a blocking solution $[1 \%$ BSA and $2 \%$ Triton $\mathrm{X}-100$ in phosphate-buffered saline (PBS)]. Thereafter, primary antibodies against $\alpha$-SMA (1:200 dilution in PBS), CK14 (1:500 in PBS), and p63 (1:100 in PBS) were added. After 1-hour incubation, slides were washed with PBS, and then secondary antibodies conjugated with $\mathrm{Cy} 2$ or $\mathrm{Cy} 3$ (at 1:200 dilution in PBS) were added for 1 hour. To detect cell nuclei, DAPI was added to the mounting medium. Negative controls included the omission of primary antibodies. Cells were viewed by fluorescence microscopy (Eclipse E80i, Nikon, Tokyo, Japan), and micrographs were taken using a digital camera (Spot, Diagnostic Instruments Inc., Sterling Heights, MI) or using a Zeiss LSM 710 confocal laser scanning microscope (Zeiss, Oberkochen, Germany).

\section{Cell Counting}

After isolation by collagenase digestion, cells were suspended in KRB and $0.5 \%$ BSA, and the number of cells was counted using a hemocytometer before plating for culture.

\section{Intracellular Calcium Measurement}

First-passage cultured lacrimal gland MECs were grown on 35-mm glass-bottom culture dishes for 24 hours. Then cells were incubated in KRB buffer with $0.5 \% \mathrm{BSA}, 8 \mu \mathrm{mol} / \mathrm{L}$ pluronic acid F127, $250 \mu \mathrm{mol} / \mathrm{L}$ sulfinpyrazone, and $0.5 \mu \mathrm{mol} / \mathrm{L}$ of fura-2/AM for 1 hour at $37^{\circ} \mathrm{C}$. Fura- 2 is a fluorescent molecule that indicates the intracellular $\left[\mathrm{Ca}^{2+}\right]$. After incubation, cells were washed with KRB buffer that contained $250 \mu \mathrm{mol} / \mathrm{L}$ sulfinpyrazone, and the dishes were observed using a $\mathrm{Ca}^{2+}$ imagining system (InCyt Im2, Intracellular Imaging, Cincinnati, OH). This system allows measurement of the ratio of fura- 2 using excitation wavelengths of 340 and $380 \mathrm{~nm}$ and an emission wavelength of $505 \mathrm{~nm}$. A mean of 30 cells per dish was selected, and intracellular $\left[\mathrm{Ca}^{2+}\right]$ was measured in each cell. A basal reading was performed for at least 15 seconds. The effect of the cholinergic agonist $\mathrm{Cch}\left(10^{-5}\right.$ to $\left.10^{-2} \mathrm{~mol} / \mathrm{L}\right)$, VIP $\left(10^{-9} \mathrm{~mol} / \mathrm{L}\right.$ to $\left.10^{-7} \mathrm{~mol} / \mathrm{L}\right)$, the $\alpha_{1}$-adrenergic agonist $\mathrm{Ph}$ $\left(10^{-6}\right.$ to $\left.10^{-3} \mathrm{~mol} / \mathrm{L}\right)$, the P2X agonist ATP $\left(10^{-7}\right.$ to $10^{-4}$ $\mathrm{mol} / \mathrm{L})$, the P2Y agonist UTP $\left(10^{-7}\right.$ to $\left.10^{-4} \mathrm{~mol} / \mathrm{L}\right)$, and high potassium chloride $(40 \mathrm{mmol} / \mathrm{L})$ in cultured MECs was evaluated by adding $100 \mu \mathrm{L}$ of each agonist to $900 \mu \mathrm{L}$ of buffer. For the potassium chloride experiments, the sodium chloride concentration was decreased by $40 \mathrm{mmol} / \mathrm{L}$. Data are presented as the change in peak intracellular $\left[\mathrm{Ca}^{2+}\right]$, 


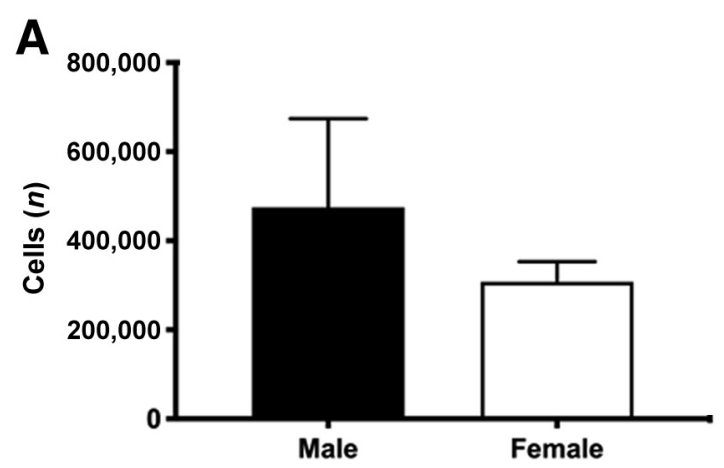

B

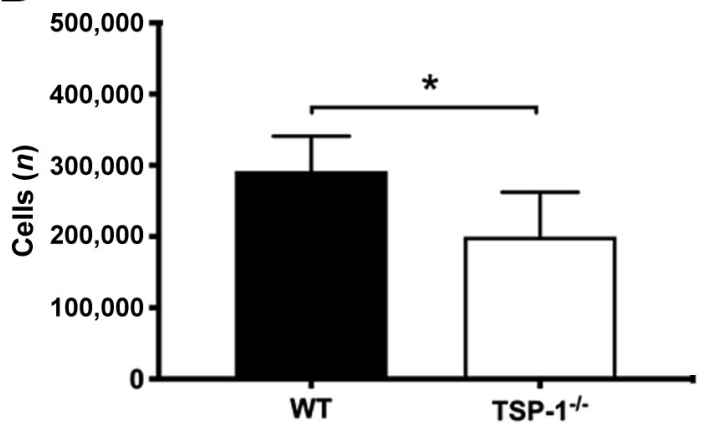

Figure 1 Number of cells isolated from the lacrimal gland of $\mathrm{C} 57 \mathrm{BL} / 6 \mathrm{~J}$ [wild type (WT)] and thrombospondin 1 null (TSP1 ${ }^{-1-}$, alias Thbs $1^{-1-}$ ) mice. After isolation, the number of cells from male and female WT mice (A) and from female WT and TSP $1^{-1-}$ mice (B) are shown. Data are expressed as means \pm SD. $n=3$ independent experiments $(\mathbf{A}) ; n=5$ independent experiments (B). ${ }^{*} P<0.05$.

which was calculated by subtracting the basal value from the intracellular $\left[\mathrm{Ca}^{2+}\right]$ peak. At least three independent experiments were performed for each condition. To calculate intracellular $\mathrm{Ca}^{2+}$ stores, extracellular $\mathrm{Ca}^{2+}$ was removed. Then cells were treated for 15 minutes with $10^{-5}$ $\mathrm{mol} / \mathrm{L}$ thapsigargin. Peak intracellular $\left[\mathrm{Ca}^{2+}\right]$ and total area under the curve were measured. After that, $\mathrm{Ca}^{2+}$ was reintroduced in the bath, and the rate of refilling was analyzed.

\section{Contraction Assays}

To analyze the contraction of MECs in response to the different agonists (Cch, VIP, Ph, ATP, UTP, and high potassium chloride), the Leica DMI 6000 live-cell imaging system from Leica Microsystems (Wetzlar, Germany) was used. Live MECs cultured from $\alpha$-SMA-GFP WT and $\mathrm{TSP} 1^{-1-}$ mice were trypsinized and plated on $35-\mathrm{mm}$ glassbottomed culture dishes as described for measurement of intracellular $\left[\mathrm{Ca}^{2+}\right]$. After 24 hours, cells were observed under the microscope under fluorescence or brightfield. After 1 minute of basal observation, the different neurotransmitters were added. Images were taken automatically every 15 seconds for 30 minutes. Time-lapse movies were created using the individual images, and the response of MECs was evaluated.

\section{Western Blot Analysis}

The expression of purinergic receptors $\mathrm{P} 2 \mathrm{X} 3, \mathrm{P} 2 \mathrm{X} 7, \mathrm{P} 2 \mathrm{Y} 1$, $\mathrm{P} 2 \mathrm{Y} 11$, and $\mathrm{P} 2 \mathrm{Y} 13$ and the housekeeping protein $\beta$-actin was measured by Western blot analysis. Cultured MECs were homogenized in radioimmunoprecipitation assay buffer [(10 mmol/L Tris-HCl pH 7.4), $150 \mathrm{mmol} / \mathrm{L} \mathrm{NaCl}, 1 \%$

\section{a-SMA-GFP mice MECs}
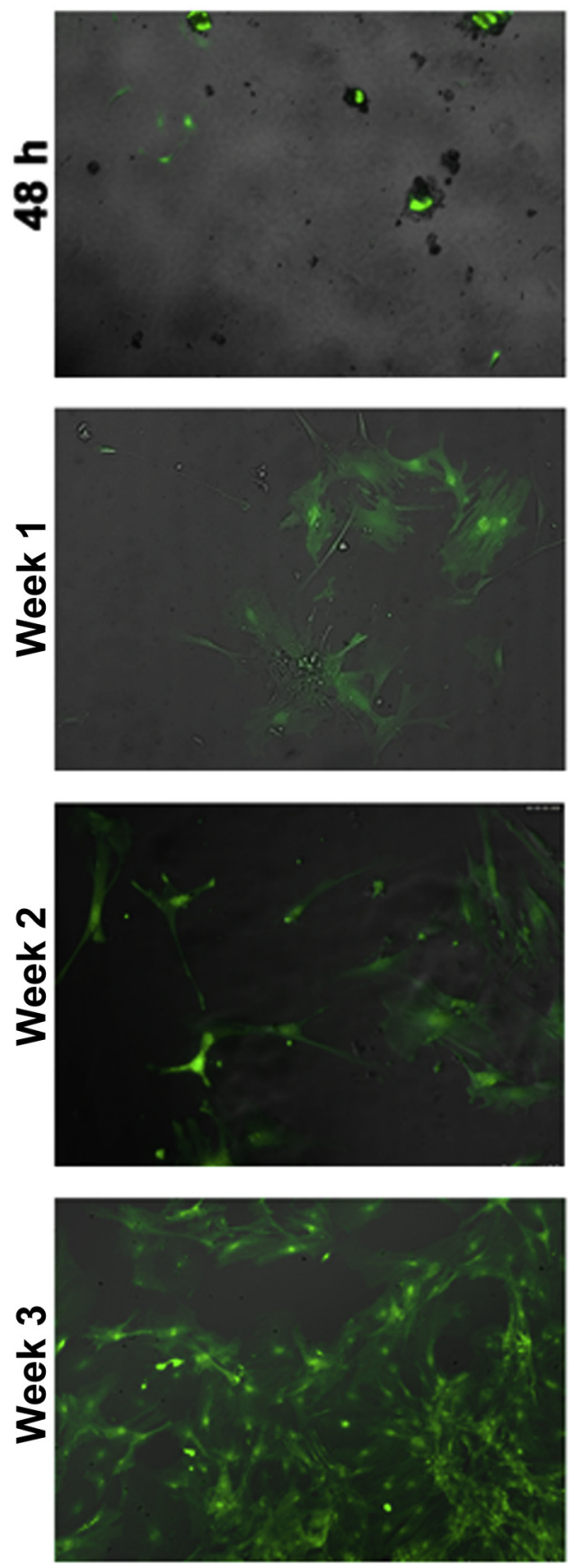

Figure 2 Growth of cultured myoepithelial cells (MECs). Digested lacrimal glands from $\alpha$-smooth muscle actin-green fluorescent protein ( $\alpha$-SMA-GFP) mice were cultured for 48 hours, 1 week, 2 weeks, and 3 weeks. Fluorescent micrographs are shown for each time point. $n=$ at least 3 separate mice. Original magnification, $\times 200$. 

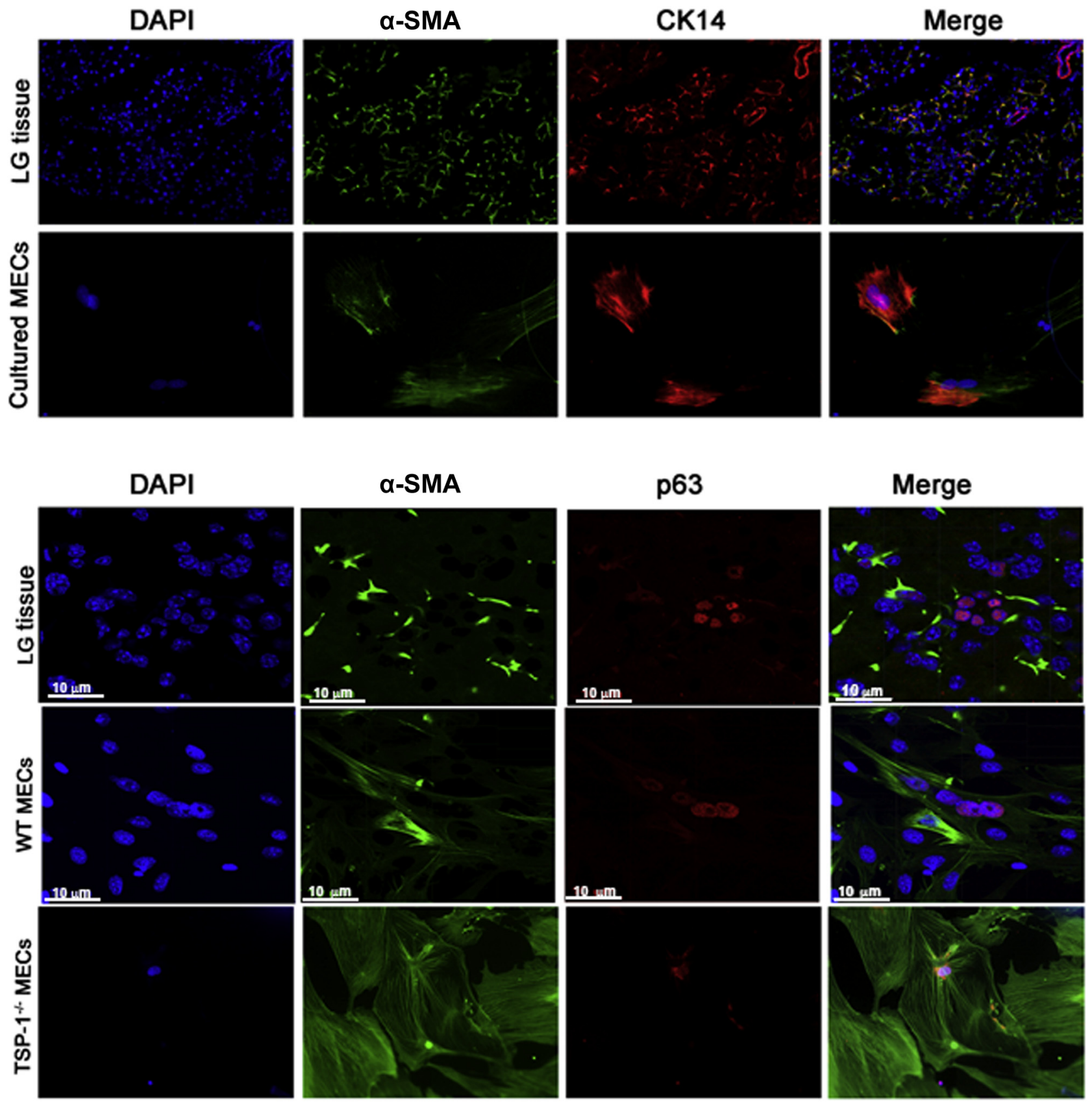

Figure 3 Identification of cultured myoepithelial cells (MECs). Immunofluorescence experiments were performed with sections of wild-type (WT) mouse lacrimal glands (LG) and cultured WT and thrombospondin 1 null (TSP1 $1^{-1-}$, alias Thbs $1^{-/-}$) MECs using $\alpha$-smooth muscle actin ( $\alpha$-SMA, shown in green) and cytokeratin 14 (CK14, shown in red) in the top panels and p63 (shown in red) in the bottom panels. Nuclei are stained with DAPI (blue). $n=3$ independent experiments. Scale bars $=10 \mu \mathrm{m}$. Original magnification, $\times 200$ (unless otherwise indicated).

deoxycholic acid, $1 \%$ Triton X-100, $0.1 \%$ SDS, and $1 \mathrm{mmol} / \mathrm{L}$ EDTA] that contained a protease inhibitor cocktail (SigmaAldrich), and cells were scraped. The homogenates were collected, sonicated, and centrifuged at $14,500 \times g$ for 10 minutes at $4^{\circ} \mathrm{C}$. Proteins were separated by SDS-PAGE using a $10 \%$ gel and processed for Western blotting. Antibodies against purinergic receptors were used at 1:500 dilution. The $\beta$-actin antibody was used at a dilution of 1:1000. Secondary antibody conjugated to horseradish peroxidase was used at a dilution of 1:2000, and immunoreactive bands were visualized by the enhanced chemiluminescence method. The films were analyzed with ImageJ software version 1.48 (NIH, Bethesda, MD; http://imagej.nih.gov/ij). Data are expressed as percentage of WT values, which were set to $100 \%$.

\section{Gene Expression Analysis by Microarray}

The expression of genes in cultured MECs derived from female C57BL/6J mice $(n=3)$ and TSP $1^{-1-}$ mice $(n=3)$, aged 6 to 8 weeks, were analyzed using RNA microarrays. Total RNA was 

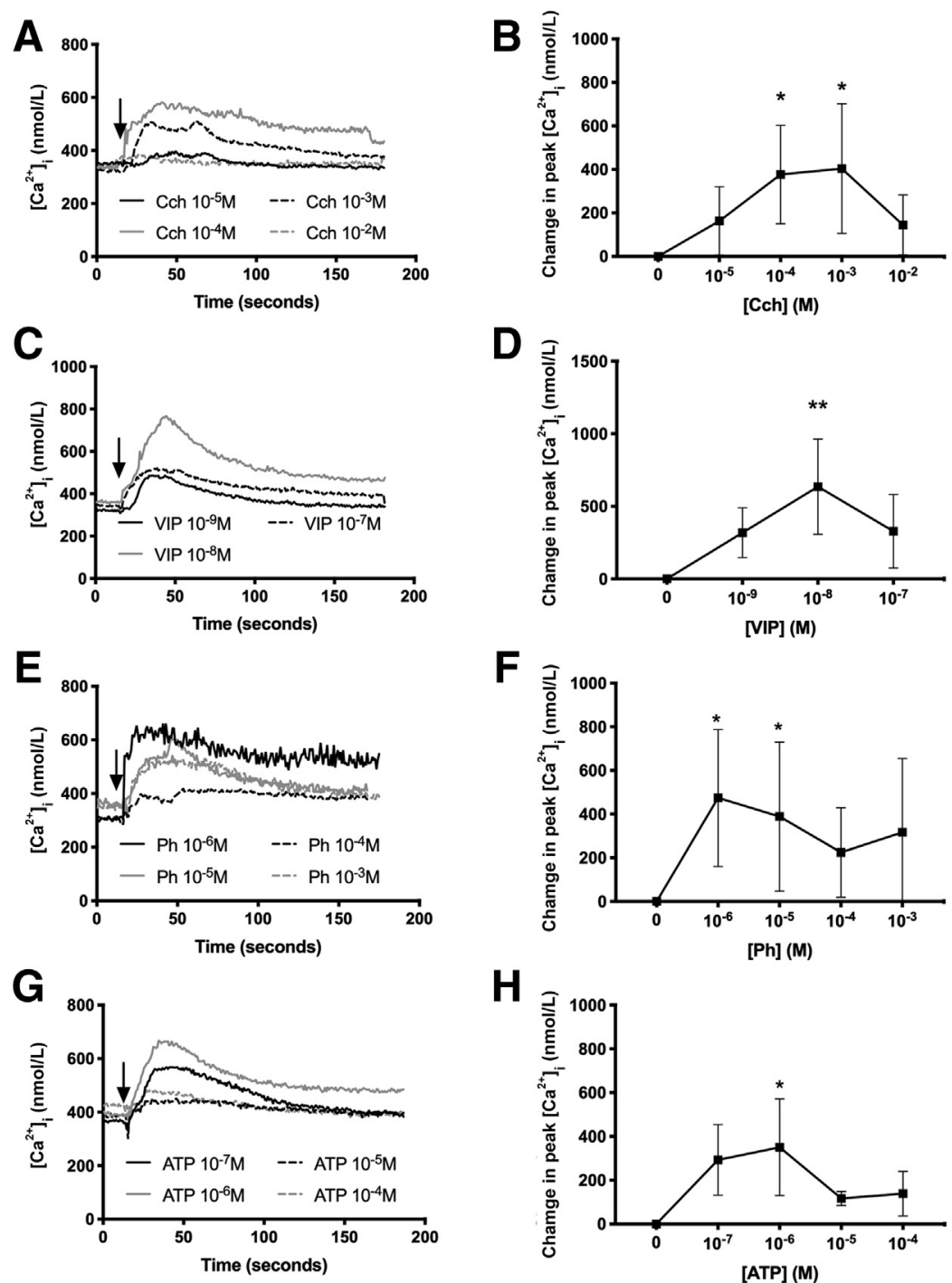

$\mathbf{F}$

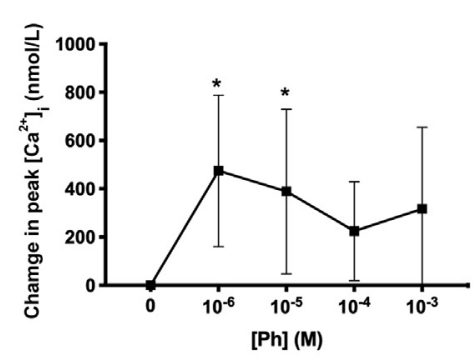

$\mathrm{H}$
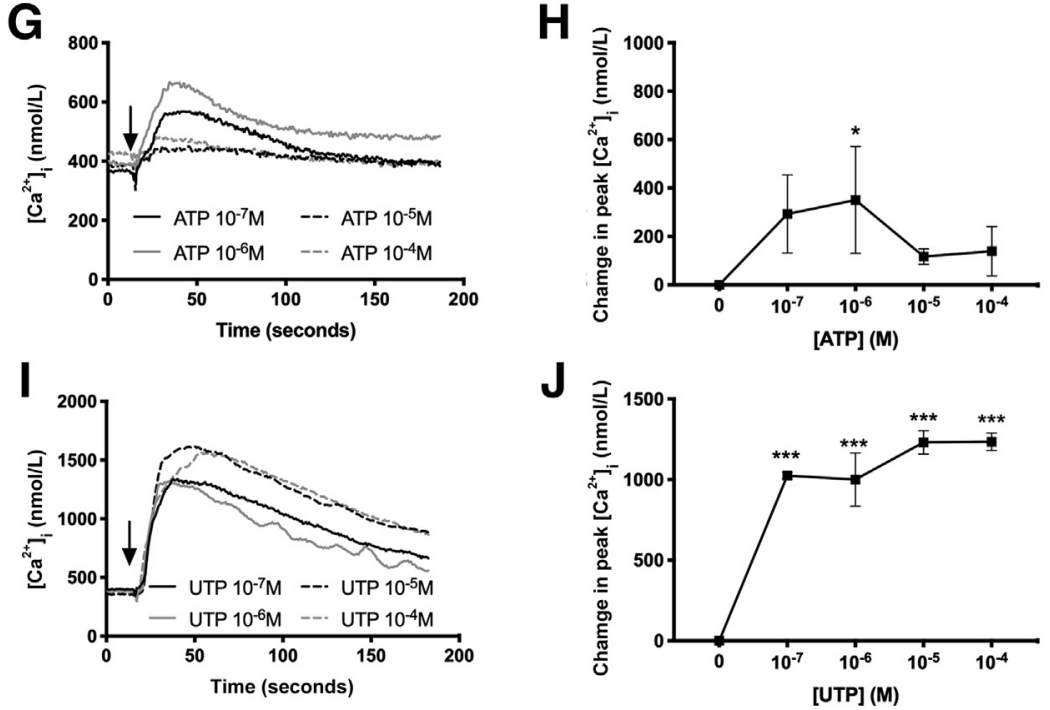

Figure 4 Cultured myoepithelial cells respond to multiple agonists to increase intracellular $\left[\mathrm{Ca}^{2+}\right]$. Cultured myoepithelial cells from $\mathrm{C} 57 \mathrm{BL} / 6 \mathrm{~J}$ (wild type) mice were stimulated with increasing concentrations of the cholinergic agonist carbachol (Cch), vasoactive intestinal peptide (VIP), the $\alpha_{1}$-adrenergic agonist phenylephrine $(\mathrm{Ph}), \mathrm{ATP}$, and UTP. Intracellular $\left[\mathrm{Ca}^{2+}\right]$ over time $(\mathbf{A}, \mathbf{C}, \mathbf{E}, \mathbf{G}$, and $\mathbf{I})$ and change in peak intracellular $\left[\mathrm{Ca}^{2+}\right](\mathbf{B}$, D, F, H, and $\mathbf{J}$ ) are shown. Data are expressed as means \pm SD. $n=$ at least 3 independent experiments performed in duplicate. ${ }^{*} P<0.05$, ${ }^{* *} P<0.01$, and ${ }^{* * *} P<0.005$ versus 0 . isolated with TRIZol. A NanoDrop ND-1000 spectrophotometer (Thermo Fisher Scientific) was used for RNA quantification. A total of $150 \mathrm{ng}$ of total RNA was processed with a GeneChip HT One-Cycle cDNA Synthesis Kit and a GeneChip HT IVT Labeling Kit (Affymetrix, Santa Clara, CA). Labeled and fragmented single-stranded cDNA was hybridized to the GeneChip Mouse Gene 2.0 ST Array (41,345 transcripts) (Affymetrix). Thereafter, the arrays were rinsed and stained using a FS-450 fluidics station (Affymetrix). Signal intensities were measured with a Hewlett Packard Gene Array Scanner 30007 G (Hewlett Packard, Palo Alto, CA), and the scanned images were processed by the Affymetrix GeneChip Command Console. The CEL files were imported into Partek Genomics Suite software version 6.6 (Partek Inc., St. Louis, MO). Robust microarray analysis was applied for normalization. Gene transcripts with a maximal signal value $<5\left(\log _{2}\right)$ across all arrays were removed to filter for low and nonexpressed genes, reducing the number of gene transcripts to 20,900 . 

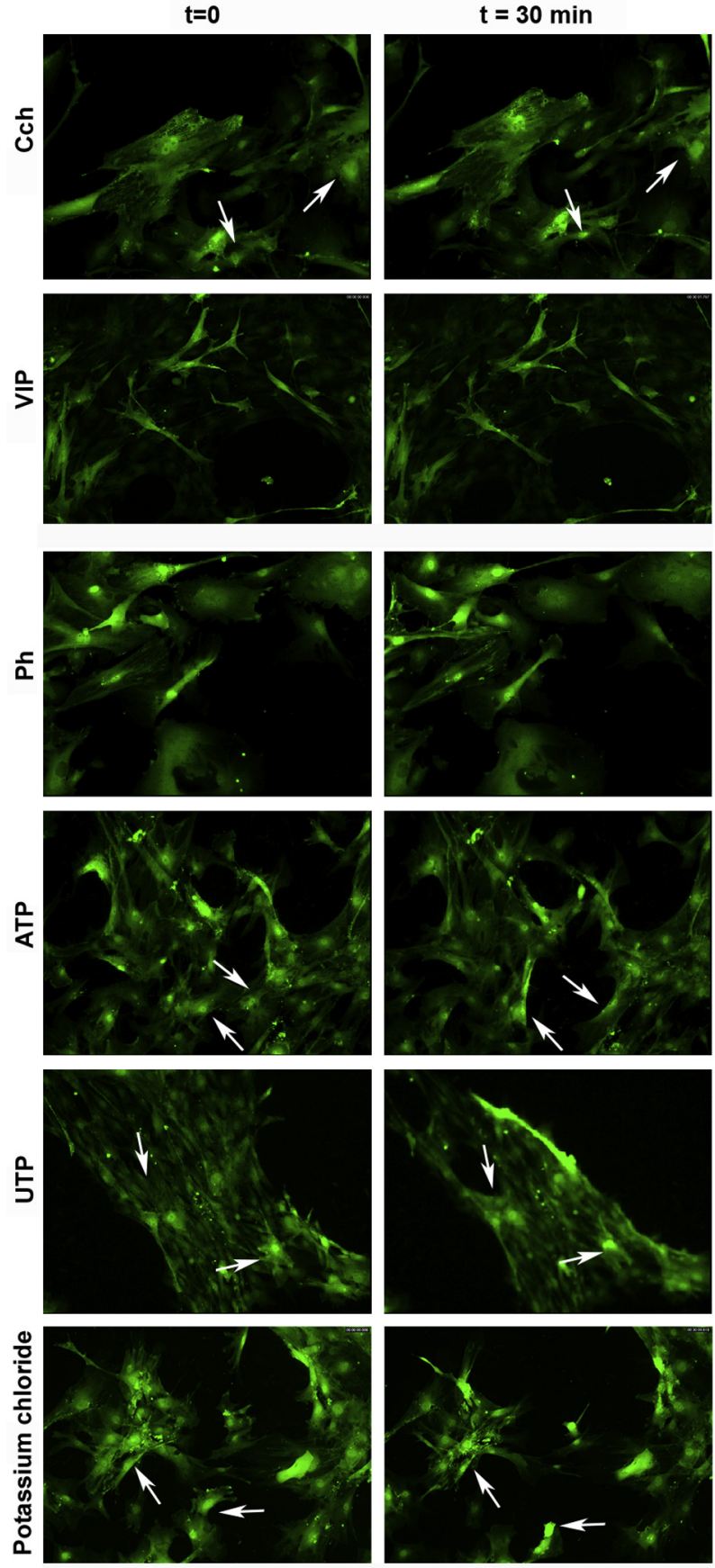

Figure 5 Cultured myoepithelial cells respond to multiple agonists to cause contraction. Cultured myoepithelial cells from $\alpha$-smooth muscle actin-green fluorescent protein mice were stimulated with the cholinergic agonist carbachol (Cch, $\left.10^{-3} \mathrm{~mol} / \mathrm{L}\right)$, vasoactive intestinal peptide (VIP, $\left.10^{-8} \mathrm{~mol} / \mathrm{L}\right)$, the $\alpha_{1}$-adrenergic agonist phenylephrine $\left(\mathrm{Ph}, 10^{-5} \mathrm{~mol} / \mathrm{L}\right)$, ATP $\left(10^{-5} \mathrm{~mol} / \mathrm{L}\right)$, UTP $\left(10^{-5} \mathrm{~mol} / \mathrm{L}\right)$, and potassium chloride $(40 \mathrm{mmol} / \mathrm{L})$. Cells are shown before addition of the agonist $(t=0$; left column) or 30 minutes after addition of agonist $(t=30$ min; right column). Arrows point at the same cells attimes 0 and 30 minutes. $n=3$ independent experiments performed in duplicate (for each duplicate, images were taken from 3 different areas). Original magnification, $\times 200$.

Differentially expressed genes between groups were identified using one-way analysis of variance analysis in the Partek Genomics Suite Software. Clustering analysis was performed using the same name module in a Partek Genomics Suite
Software. For expression comparisons of different groups, profiles were compared using a one-way analysis of variance model. Data are presented as fold changes and $P$ values.

\section{Data Presentation and Statistical Analysis}

Data are presented as means $\pm \mathrm{SD}$. The $t$-test was performed when comparing two groups. For comparing more than two groups, a one-way analysis of variance was performed after ensuring equality of variance. A Tukey test was then performed ad hoc. In the absence of variance equality, a Kruskal-Wallis test was performed. Differences were considered to be significant at $P \leq 0.05$.

\section{Results}

Lacrimal Gland MECs Isolated from C57BL/6J, SMA-GFP, and TSP1 ${ }^{-/-}$Mice Can Be Grown in Culture

No difference was found in the number of cells obtained from male (474,667 $\pm 199,613$ cells) compared with female WT mice $(307,333 \pm 45,553$ cells $)(P=0.2298)$ (Figure 1A). The number of cells obtained from $\alpha$-SMA-GFP mice was similar to the number obtained from C57BL/6J WT mice. In contrast, fewer cells were obtained from female TSP $1^{-1-}$ mice compared with WT mice $(199,833 \pm 62,317$ versus $291,800 \pm 49,357$, $P=0.0257$ ) (Figure 1B).

MECs obtained from the three different types of mice used in this study: C57BL/6J (WT), $\alpha$-SMA-GFP, and $\mathrm{TSP}^{-1-}$ mice, were isolated and expanded in vitro. MEC growth over time is shown (Figure 2) for $\alpha$-SMA-GFP mice because of their visibility. There were no evident morphologic or behavioral differences between the cells grown from the three strains of mice.

\section{MECs in Culture Express the Same Cell Markers Observed in the Native Tissue}

To characterize the cultured cells and confirm their identity at the end of the cell culture period, immunofluorescence staining was performed using antibodies against different MEC markers: $\alpha$-SMA, CK14, and the proliferation marker p63 in WT lacrimal gland as well as MECs cultured from WT and TSP1 ${ }^{-1-}$ mouse lacrimal gland (Figure 3). Most cells in culture expressed $\alpha$-SMA and CK14, as do MECs in the lacrimal gland. In addition, a large number of cultured cells expressed p63. Therefore, the overwhelming majority of cells in culture were MECs.

\section{Cch, VIP, Ph, ATP, UTP Increase Intracellular $\left[\mathrm{Ca}^{2+}\right]$ in} Mouse Lacrimal Gland MECs

An increase in intracellular $\left[\mathrm{Ca}^{2+}\right]$ is a well-established second messenger system for cell contraction as well as a myriad of other cellular functions, and for that reason, intracellular 

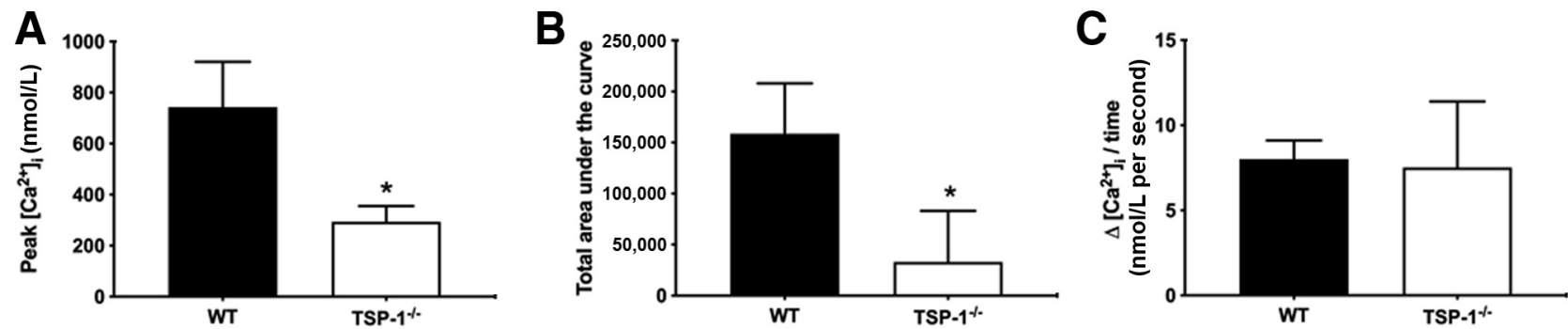

Figure 6 Myoepithelial cells cultured from thrombospondin 1 null (TSP1 ${ }^{-1-}$, alias Thbs $1^{-1-}$ ) mice have altered $\mathrm{Ca}^{2+}$ stores compared with wild-type (WT) mice. Myoepithelial cells cultured from C57BL/6J (WT) or TSP1 ${ }^{-1-}$ mice were stimulated with thapsigargin in the absence of extracellular $\mathrm{Ca}^{2+}$ and intracellular $\left[\mathrm{Ca}^{2+}\right]$ was measured. Change in peak intracellular $\left[\mathrm{Ca}^{2+}\right](\mathbf{A})$ and the area under the curve $(\mathbf{B})$ are shown. Extracellular $\mathrm{Ca}^{2+}$ was reintroduced and the rate of refilling of the stores measured (C). Data are expressed as means \pm SD. $n=3$ independent experiments performed in duplicate. ${ }^{*} P<0.05$ versus $\mathrm{WT}$. $\mathrm{KCl}$, potassium chloride.

$\left[\mathrm{Ca}^{2+}\right]$ is tightly regulated in cells. Intracellular $\left[\mathrm{Ca}^{2+}\right]$ was measured in cultured MECs before and after addition of the different neural agonists (Figure 4). Cch, a cholinergic agonist, significantly increased intracellular $\left[\mathrm{Ca}^{2+}\right]$ at $10^{-4} \mathrm{~mol} / \mathrm{L}$ and $10^{-3} \mathrm{~mol} / \mathrm{L}$ to maximum values of $376.98 \pm 226.29$ and $403.60 \pm 298.54 \mathrm{nmol} / \mathrm{L}$, respectively (Figure 4, A and B). VIP at $10^{-8} \mathrm{~mol} / \mathrm{L}$ increased intracellular $\left[\mathrm{Ca}^{2+}\right]$ to a maximum value of $635.04 \pm 328.00 \mathrm{nmol} / \mathrm{L}$ (Figure 4 , $\mathrm{C}$ and $\mathrm{D}) \mathrm{Ph}$, an $\alpha$-adrenergic agonist, produced a significant increase in peak intracellular $\left[\mathrm{Ca}^{2+}\right]$ with maximum values of $474.40 \pm 313.60$ and $388.56 \pm 341.36 \mathrm{nmol} / \mathrm{L}$ at $10^{-6} \mathrm{~mol} / \mathrm{L}$ and $10^{-5} \mathrm{~mol} / \mathrm{L}$, respectively (Figure $4, \mathrm{E}$ and $\mathrm{F}$ ). ATP, an activator of $\mathrm{P} 2 \mathrm{X}$ receptors, increased peak intracellular $\left[\mathrm{Ca}^{2+}\right]$ to $350.68 \pm 220.39 \mathrm{nmol} / \mathrm{L}$ at $10^{-6} \mathrm{~mol} / \mathrm{L}$ (Figure $4, \mathrm{G}$ and $\mathrm{H}$ ). $\mathrm{UTP}$, an activator of $\mathrm{P} 2 \mathrm{Y}$ receptors, increased peak intracellular $\left[\mathrm{Ca}^{2+}\right]$ to a maximum value of $1234.52 \pm 53.68 \mathrm{nmol} / \mathrm{L}$ at $10^{-4} \mathrm{~mol} / \mathrm{L}$ (Figure 4, I and J). In summary, all neural agonists tested increased peak intracellular $\left[\mathrm{Ca}^{2+}\right]$ in cultured lacrimal gland MECs with a rank order of effectiveness of UTP greater than VIP greater than $\mathrm{Ph}$ greater than Cch greater than ATP.

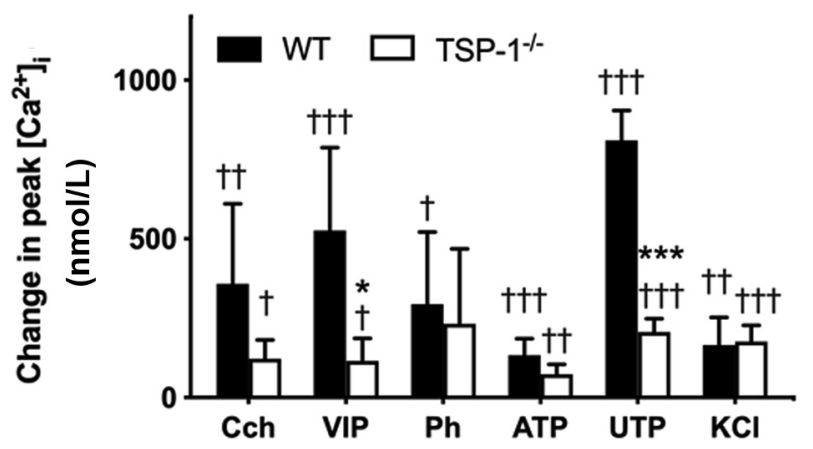

Figure 7 Difference in intracellular $\left[\mathrm{Ca}^{2+}\right]$ in response to multiple agonists in myoepithelial cells cultured from thrombospondin 1 null (TSP1 ${ }^{-/-}$, alias Thbs1 ${ }^{-/-}$) compared with wild-type (WT) mice. Myoepithelial cells were cultured from $\mathrm{C57BL} / 6 \mathrm{~J}$ (WT) or TSP1 ${ }^{-1-}$ mice. Change in peak intracellular $\left[\mathrm{Ca}^{2+}\right]$ was measured in response to the cholinergic agonist carbachol (Cch, $10^{-3} \mathrm{~mol} / \mathrm{L}$ ), vasoactive intestinal peptide (VIP, $\left.10^{-8} \mathrm{~mol} / \mathrm{L}\right), \alpha_{1}$-adrenergic agonist phenylephrine $\left(\mathrm{Ph}, 10^{-5} \mathrm{~mol} / \mathrm{L}\right)$, ATP $\left(10^{-5} \mathrm{~mol} / \mathrm{L}\right)$, UTP $\left(10^{-5} \mathrm{~mol} / \mathrm{L}\right)$, and potassium chloride $(\mathrm{KCl}, 40 \mathrm{mmol} / \mathrm{L})$. Data are expressed as means \pm SD. $n=$ at least 3 independent experiments performed in duplicate. ${ }^{*} P<0.05,{ }^{*} P>0.005$ versus $W T$; ${ }^{\dagger} P<0.05$, ${ }^{\dagger \dagger} P<0.01$, and ${ }^{\dagger \dagger} P<0.005$ peak value versus 0 .

\section{Cch, ATP, and UTP Produce Lacrimal Gland MEC Contraction}

To determine whether lacrimal gland MECs were able to contract in response to the neurotransmitters and purines tested previously, cultured $\alpha$-SMA-GFP mice-derived MECs were observed under the microscope for 30 minutes. After a short time of basal observation, the different compounds were added, and the reaction of cells was recorded. A small contraction was observed in a few cells after the addition of $10^{-3} \mathrm{~mol} / \mathrm{L}$ Cch (Figure 5 and Supplemental Video S1), whereas no response was detected after exposure to $10^{-8} \mathrm{~mol} / \mathrm{L}$ VIP (Figure 5 and Supplemental Video $\mathrm{S} 2$ ) or $10^{-5} \mathrm{~mol} / \mathrm{L} \mathrm{Ph}$ (Figure 5 and Supplemental Video S3). In contrast, when cells were exposed to the purines ATP $\left(10^{-5} \mathrm{~mol} / \mathrm{L}\right)$ and UTP $\left(10^{-5} \mathrm{~mol} / \mathrm{L}\right)$, strong contractions was observed (Figure 5 and Supplemental Videos S4 and S5). The purinergic agonist UTP caused the largest contractile response. In addition, an elevated extracellular potassium chloride concentration, which depolarizes excitable cells, such as nerve and muscle, and causes excitation and contraction, respectively, was tested. High potassium chloride did not induce MEC contraction in the $\alpha$-SMA-GFP-derived MECs (Figure 5 and Supplemental Video S6). To ensure cell viability throughout the contraction, live dead assays were performed after treatment. None of the treatments altered cell viability (data not shown).

Intracellular $\mathrm{Ca}^{2+}$ Response Is Altered in MECs Derived from TSP1 ${ }^{-/-}$Compared with WT Mice

To explore differences between MECs derived from WT and $\mathrm{TSP}^{-1-}$ mice, it was determined whether differences exist between WT and TSP1 ${ }^{-1-}$ mouse intracellular $\mathrm{Ca}^{2+}$ stores. To this end, thapsigargin, a compound that inhibits sarcoendoplasmic reticulum $\mathrm{Ca}^{2+}$ ATPases, was used, thereby emptying intracellular $\mathrm{Ca}^{2+}$ stores in the absence of extracellular $\mathrm{Ca}^{2+}$. $\mathrm{The} \mathrm{Ca}^{2+}$ release in response to thapsigargin indicates the size of the stores. Then, with reintroduction of $\mathrm{Ca}^{2+}$ in the buffer, it is possible to measure the rate of $\mathrm{Ca}^{2+}$ influx to refill the stores. 
Table 2 Myoepithelial Cell Contraction

\begin{tabular}{lll}
\hline Stimulant & WT & TSP1 ${ }^{-/-}$ \\
\hline Carbachol $\left(10^{-3} \mathrm{~mol} / \mathrm{L}\right)$ & $+/-$ & - \\
VIP $\left(10^{-8} \mathrm{~mol} / \mathrm{L}\right)$ & - & - \\
Phenylephrine $\left(10^{-5} \mathrm{~mol} / \mathrm{L}\right)$ & - & + \\
ATP $\left(10^{-5} \mathrm{~mol} / \mathrm{L}\right)$ & ++ & $+/-$ \\
UTP $\left(10^{-5} \mathrm{~mol} / \mathrm{L}\right)$ & ++ & + \\
Potassium chloride $(40 \mathrm{mmol} / \mathrm{L})$ & + & + \\
\hline
\end{tabular}

$n=3$.

- , no contraction; $+/-$, small contraction in some cells; + , contraction; ++ , large contraction; $\mathrm{TSP}^{-/-}\left(\right.$Thbs $\left.^{-1-}\right)$, thrombospondin 1 null; VIP, vasoactive intestinal peptide; WT, wild type.

In $\mathrm{TSP}^{-1-}$ compared with WT MECs, a significant decrease of $60.43 \%$ in peak $\mathrm{Ca}^{2+}$ (Figure 6A) and $79.13 \%$ in area under the curve, which indicates the size of the $\mathrm{Ca}^{2+}$ store (Figure 6B), is observed. No differences were found in the rate of $\mathrm{Ca}^{2+}$ influx (Figure 6C). These data indicate that calcium stores are smaller in $\mathrm{TSP}^{-\prime-}$ compared with WT MECs.

The effect of a maximum concentration (Figure 4) of the different neural agonists on peak intracellular $\left[\mathrm{Ca}^{2+}\right]$ was studied in WT- and TSP1 $1^{-l-}$-derived MECs (Figure 7). When $10^{-3} \mathrm{~mol} / \mathrm{L}$ Cch was used, there was a decrease in peak intracellular $\left[\mathrm{Ca}^{2+}\right]$ between WT and TSP1 $1^{-1-}$ MECs,
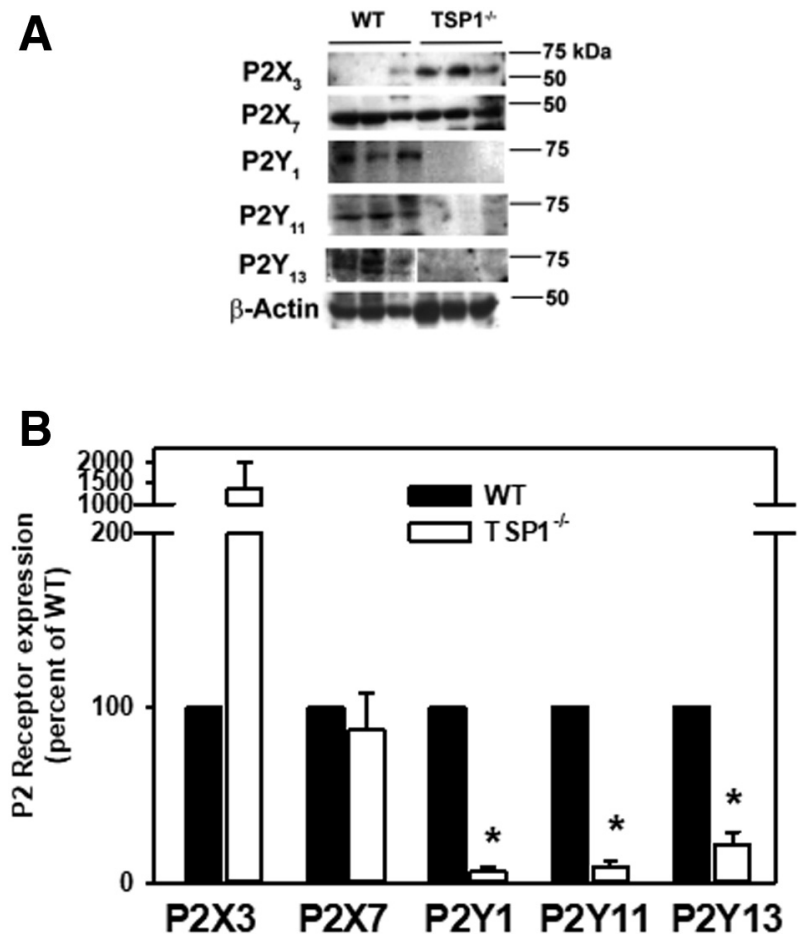

Figure 8 Amount of $P 2 X$ and $P 2 Y$ purinergic receptor subtypes in myoepithelial cells cultured from thrombospondin 1 null (TSP1 ${ }^{-1-}$, alias Thbs $1^{-/}$) compared with wild-type (WT) mice. Myoepithelial cells were cultured from C57BL/6J (WT) or TSP1 ${ }^{-/-}$mice. Cells were lysed and subjected to Western blot analysis. Western blots (A, each lane represents a different animal) and densitometric scans for $\mathrm{P} 2 \mathrm{X}$ and $\mathrm{P} 2 \mathrm{Y}$ receptors $(\mathbf{B})$ are shown. Data are expressed as means \pm SD. $n=3$ independent experiments. ${ }^{*} P<0.05$ versus WT mice that were set to 100 . but it was not significant. However, when $10^{-8} \mathrm{~mol} / \mathrm{L}$ VIP is added, the response in TSP1 ${ }^{-1-}$ MECs was $78.05 \%$ lower than that of WT MECs $(115.68 \pm 70.97 \mathrm{nmol} / \mathrm{L}$ compared with $526.92 \pm 261.03 \mathrm{nmol} / \mathrm{L}, P=0.041)$. The response to $10^{-5} \mathrm{~mol} / \mathrm{L} \mathrm{Ph}$ and $10^{-5} \mathrm{~mol} / \mathrm{L}$ ATP was similar in both WT and TSP $1^{-1-}$ MECs. In contrast, the stimulation of P2Y receptors by $10^{-5} \mathrm{~mol} / \mathrm{L}$ UTP was $74.51 \%$ lower in TSP $1^{-1}$ - MECs than in WT MECs $(206.69 \pm 41.78 \mathrm{nmol} / \mathrm{L}$ versus $810.94 \pm 93.32 \mathrm{nmol} / \mathrm{L}, P=0.0005)$. High potassium chloride $(40 \mathrm{mmol} / \mathrm{L})$ increased the intracellular $\left[\mathrm{Ca}^{2+}\right]$ to a small extent in WT MECs, which was unaltered in TSP1 ${ }^{-1-}$ MECs. VIP and UTP gave the largest $\mathrm{Ca}^{2+}$ responses, and these responses were the only ones significantly decreased in $\mathrm{TSP}^{-/-}$compared with WT MECs.

\section{MEC Contractile Response Is Impaired in $\mathrm{TSP}^{-/-}$Mice}

To determine whether the contractile response mediated by the neural agonists studied was altered in $\mathrm{TSP}^{-1-}$ mice, contraction assays were performed in these mouse MECs and compared with MEC contraction obtained in $\alpha$ SMA-GFP WT mice (Table 2). Neither Cch nor VIP induced any contractile response in WT or TSP1 ${ }^{-1-}$ MECs. In WT mice, cells did not contract; however, some cells from $\mathrm{TSP}^{-/-}$mice contracted when $10^{-5} \mathrm{~mol} / \mathrm{L} \mathrm{Ph}$ was added. Regarding the purinergic agonists, $10^{-5} \mathrm{~mol} / \mathrm{L}$ ATPexposed cells contracted in WT mice but only exhibited a small contraction in TSP1 $1^{-1-}$ mice. In contrast, $10^{-5} \mathrm{~mol} / \mathrm{L}$ UTP exposed cells had a large contraction in WT mice that was substantially decreased in TSP $1^{-/}$mice. WT MECs gave a small contraction in response to high potassium chloride that was not altered in TSP1 ${ }^{-1-}$ MECs. The purinergic agonists ATP and UTP gave the largest contractile responses, and these responses were the ones decreased in $\mathrm{TSP}^{-1-}$ compared with WT MECs.

\section{Expression of Purinergic Receptors Is Altered in TSP $1^{-/-}$Mice}

Because ATP and UTP, which bind to purinergic receptors, caused an increase in intracellular $\left[\mathrm{Ca}^{2+}\right]$ and contraction of MECs, it was determined whether there was a change in the expression of these receptors in WT compared with TSP1 ${ }^{-1-}$ mice. It was previously found that rat lacrimal gland expressed P2X3, P2X7, P2Y1, P2Y11, and P2Y13 receptors. $^{2,3}$ Therefore, the expression of these receptors in cultured mouse MECs was investigated. Cultured MECs from WT and TSP1 ${ }^{-1-}$ mice were homogenized and proteins separated by Western blot analysis and the amount of purinergic receptors determined. There was an increase in the amount of $\mathrm{P} 2 \mathrm{X} 3$ but no change in $\mathrm{P} 2 \mathrm{X} 7$ receptors between WT and $\mathrm{TSP}^{-1-}$ mice (Figure 8). In contrast, there was a decrease in the expression of P2Y1, P2Y11, and P2Y13 receptors in $\mathrm{TSP}^{-1-}$ mice compared with WT mice $[6.0 \% \pm 5.4 \%, 8.5 \% \pm 7.0 \%$, and $22.0 \% \pm 12.4 \%$ of WT values, respectively (set to 100\%)] (Figure 8). Thus, P2X3 

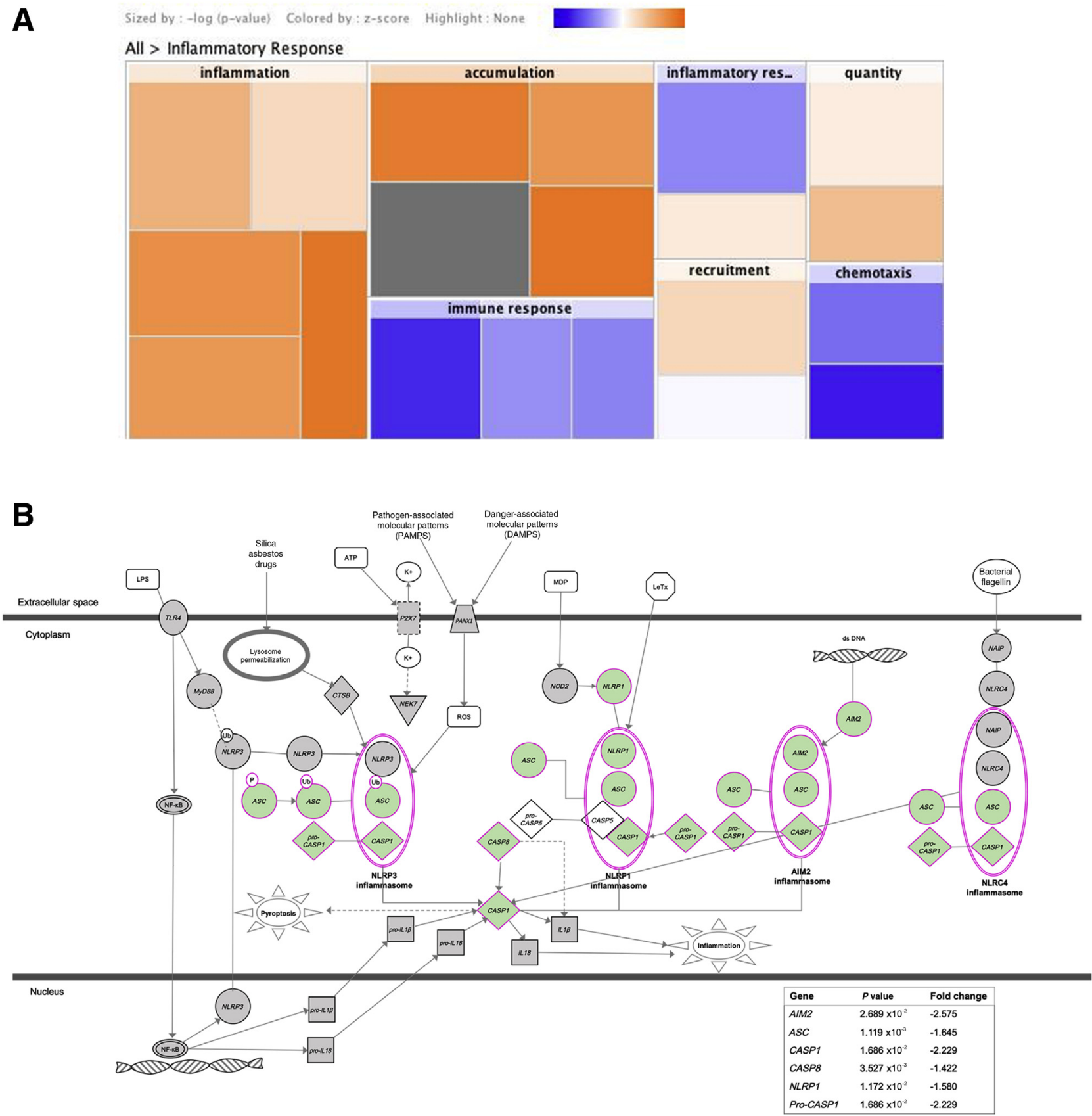

Figure 9 Gene expression is altered in lacrimal gland myoepithelial cells from thrombospondin 1 null (TSP1 ${ }^{-/-}$, alias Thbs $1^{-/-}$) mice compared with wildtype (WT) mice. Gene expression of myoepithelial cells obtained from three WT and three TSP1 ${ }^{-1-}$ mice was analyzed by microarray. A: Ingenuity pathway analysis heat map obtained by performing core analysis using a microarray data set. Increase of gene activation is shown in orange and decrease in blue. Data indicate an important increase of different sets of genes related to inflammation. B: Inflammasome pathway schematic showing $P$ value and fold change of genes AIM2 (Aim2), ASC (Pycard), CASP1 (Casp1), CASP8 (Casp8), NLRP1 (Nlrp1a), and Pro-CASP1 (Casp1) involved in the pathway. The components of the pathway that are differentially expressed in TSP1 ${ }^{-1-}$ compared with WT myoepithelial cells are shown in green. Images in $\mathbf{A}$ and $\mathbf{B}$ were generated with QIAGEN Ingenuity Pathway Analysis with permission to reproduce from QIAGEN Silicon Valley (Redwood City, CA).

receptors were increased and $\mathrm{P} 2 \mathrm{Y}$ receptors lost in $\mathrm{TSP}^{-1-}$ MECs.

\section{Gene Expression Is Altered in TSP1 ${ }^{-/-}$Mice MECS}

Using microarray, the expression of 20,900 genes in MECs of WT and TSP1 ${ }^{-1-}$ mice was analyzed [data available at Gene Expression Omnibus (http://www.ncbi.nlm.nih.gov/ geo; accession number GSE150771). The levels of Acta2 mRNA, which encodes for the SMA protein, was one of the highest of all the analyzed genes in both $\mathrm{TSP}^{-1-}$ and WT cultured cells, confirming that they are MECs. It was found that 2005 genes had significantly different expression levels in $\mathrm{TSP}^{-I-}$ lacrimal gland MECs compared with WT MECs. These data indicate statistically significant differences in the expression of the genes that encode for 
the thrombospondins TSP1 ( -1.60 -fold reduction, $P=0$. 0053), TSP2 (Thbs2, 2.02-fold increase, $P=0.006$ ), and TSP3 (Thbs3, 1.42-fold increase, $P=0.0039$ ) and in other extracellular matrix components, such as collagen I $\alpha 1$ (Collal, 1.46-fold increase, $P=0.023$ ), collagen I $\alpha 2$ (Colla2, 1.42-fold increase, $P=0.003$ ), and fibronectin 1 (Fnl, 1.20-fold increase, $P=0.031$ ), among others. Increased levels of the proinflammatory cytokine $I L-6(I l 6,1$. 54-fold increase in $\mathrm{TSP}^{-1-}$ MECs compared with WT MECs, $P=0.016$ ) and reduced expression of IL-10 receptor $\beta$ (IllOrb, -1.54 -fold decrease, $P=0.032$ ), a receptor for the anti-inflammatory cytokine IL-10, were observed. In addition, data indicate a significant decreased of the purinergic receptor mRNA genes $P 2 r x l(-1.25, P=0.040)$, $P 2 r x 4$ (-1.35, $P=0.049)$, and P2ryl3 $(-2.33, P=0$. 0018) in TSP $1^{-1-}$ compared with WT MECs. Furthermore, signaling pathway analyses revealed that several inflammatory pathways became activated in the TSP1 $1^{-1-}$ mice MECs compared with WT ones (Figure 9A), whereas inflammasome pathways, including genes such as ASC (Pycard, -1.6, $P=0.001)$ or Caspl $(-2.2, P=0.0168)$, were downregulated (Figure 9B).

\section{Discussion}

In this study, we hypothesized that lacrimal gland MEC function regulated by neural agonists was altered in inflammatory disease states, such as that of dry eye disease, represented in the spontaneously developed TSP1 ${ }^{-1-}$ mouse model of Sjögren syndrome. The calcium dynamics and contraction responses of lacrimal gland MECs were analyzed. Stimulation of MECs with neurotransmitters, purinergic agonists, and high potassium chloride all increased intracellular $\mathrm{Ca}^{2+}$, but not all of them stimulated contraction. Our results indicate the presence of inositol trisphosphate-sensitive $\mathrm{Ca}^{2+}$ stores in MECs and found that use of high potassium chloride increases intracellular $\left[\mathrm{Ca}^{2+}\right]$ and stimulates contraction, suggesting the possibility that voltage-sensitive $\mathrm{Ca}^{2+}$ channels are present in the plasma membrane of MECs. These two independent mechanisms to increase intracellular $\left[\mathrm{Ca}^{2+}\right]$ are also present in smooth muscle. ${ }^{22}$ To date, there is no published evidence about the mechanism by which contraction is controlled in MECs or about the role of different $\mathrm{Ca}^{2+}$ stores.

The pattern of which agonists induced increases in intracellular $\left[\mathrm{Ca}^{2+}\right]$ and which induced stimulation of contraction in MECs is complex, consistent with different independent modes of $\mathrm{Ca}^{2+}$ handling. In the first pattern of handling, used by VIP, Cch, $\mathrm{Ph}$, and ATP, the increase in intracellular $\left[\mathrm{Ca}^{2+}\right]$ did not correlate with the increase in contraction. The second pattern, used by high potassium chloride and UTP, caused the same magnitude increase in both $\mathrm{Ca}^{2+}$ and contraction (small in high potassium chloride and large in UTP).

There are three different agonist-activated mechanisms that cause an increase in intracellular $\left[\mathrm{Ca}^{2+}\right]$ and stimulation of contraction: i) activation of G-protein-coupled receptors (used by VIP, cholinergic agonists, $\alpha_{1}$-adrenergic agonists, and UTP) whose response depends on intracellular $\mathrm{Ca}^{2+}$ stores, ii) nonexcitable ion channels (used by ATP on activation of $\mathrm{P} 2 \mathrm{X}$ receptors), and iii) excitable ion channels (used by high potassium chloride). The two last mechanisms cause influx of extracellular $\mathrm{Ca}^{2+}$ to increase intracellular $\left[\mathrm{Ca}^{2+}\right]$. This complexity is consistent with different independent modes of $\mathrm{Ca}^{2+}$ handling and their connection with contraction. Further experimentation is needed to determine the mechanisms of $\mathrm{Ca}^{2+}$ handling and of contraction that could explain the different MEC functional responses.

Because TSP1 is present both intracellularly and extracellularly and each molecule of TSP1 is well known to bind multiple $\mathrm{Ca}^{2+},{ }^{22}$ it is not surprising that there were substantial changes in MEC function in cells isolated from TSP1 $1^{-1-}$ compared with WT mice. In the present study, thapsigargin releasable intracellular $\mathrm{Ca}^{2+}$ stores were decreased in $\mathrm{TSP}^{-/-}$ compared with WT MECs, which could account for the decrease in intracellular $\left[\mathrm{Ca}^{2+}\right]$ on VIP and UTP stimulation but not for the lack of change in response to cholinergic or $\alpha_{1^{-}}$ adrenergic agonists. A decrease in the intracellular $\mathrm{Ca}^{2+}$ stores in TSP $1^{-l-}$ compared with WT MECs could account for the decrease in contraction in response to the G-protein-coupled receptor cholinergic agonists, ATP, and UTP. However, it does not explain why VIP does not induce contraction and $\alpha_{1^{-}}$ adrenergic agonist-induced contraction is increased in $\mathrm{TSP}^{-1-}$ compared with WT MECs. Further study of MEC $\mathrm{Ca}^{2+}$ handling is needed.

In the present study, cholinergic and $\alpha_{1}$-adrenergic agonists induced a similar increase in intracellular $\left[\mathrm{Ca}^{2+}\right]$, but cholinergic agonists caused a contraction and $\alpha_{1}$-adrenergic agonists did not. In TSP1 ${ }^{-l-}$ compared with WT MECs, the cholinergic intracellular $\mathrm{Ca}^{2+}$ and induced contraction response was decreased, whereas the $\alpha_{1}$-adrenergic agonist-induced contraction response was increased. In the lacrimal gland, acini cholinergic and $\alpha_{1}$-adrenergic agonists use different cellular signaling pathways, including $\mathrm{Ca}^{2+}$, to stimulate secretion. ${ }^{4} \mathrm{M}_{3}$ acetylcholine receptors used by cholinergic agonists in the acini are present on MECs, ${ }^{23}$ but the presence of the $\alpha_{1 \mathrm{D}}$ adrenergic receptor, used by $\alpha_{1}$-adrenergic agonists, has not been published. It is likely, however, that cholinergic and $\alpha_{1}$-adrenergic agonists use different $\mathrm{Ca}^{2+}$ handling mechanisms in MECs, which accounts for the different functional responses to these two agonists in TSP1 ${ }^{-l-}$ compared with WT MECs.

UTP and ATP activate different types of purinergic receptors. ${ }^{23}$ UTP activates the G-protein-coupled receptors $\mathrm{P} 2 \mathrm{Y} 2$, P2Y4, P2Y6, and P2Y11. ATP activates the ion channel receptors $\mathrm{P} 2 \mathrm{X} 1-7$ and the G-protein-coupled receptors P2Y11 and P2Y13. To date, P2X3, P2X7, P2Y1, $\mathrm{P} 2 \mathrm{Y} 11$, and $\mathrm{P} 2 \mathrm{Y} 13$ were detected in mouse and rat MECs, and its expression was confirmed in our cultured MECs. Activation of both $\mathrm{P} 2 \mathrm{X} 3$ and $\mathrm{P} 2 \mathrm{X} 7$ receptors by ATP and select $\mathrm{P} 2 \mathrm{Y}$ receptors by UTP causes a significant increase in intracellular $\left[\mathrm{Ca}^{2+}\right]$ and stimulation of contraction in WT MECs. When MECs from WT mice were compared with 
MECs from $\mathrm{TSP}^{-1-}$ mice, the intracellular $\left[\mathrm{Ca}^{2+}\right]$ stimulated with UTP was significantly decreased, whereas the response to ATP was not. The fact that the amount of P2X3 receptor in MECs from TSP $1^{-l-}$ mice was increased could account for the lack of decrease in the ATP response. In contrast, the amount of three P2Y receptors (P2Y1, P2Y11, and $\mathrm{P} 2 \mathrm{Y} 13)$ was significantly decreased in MECs from $\mathrm{TSP} 1^{-1-}$ compared with WT mice. This finding is consistent with a decrease in stimulation by the P2Y agonist UTP in $\mathrm{TSP}^{-1-}$ compared with WT MECs.

A lower number of cells were obtained from $\mathrm{TSP}^{-1-}$ mice compared with female WT mice. It was recently found that the $\mathrm{TSP}^{-1-}$ mouse model of Sjögren syndrome exhibited decreased lacrimal gland innervation ${ }^{19}$ and decreased size of MECs in two other mouse models of Sjögren syndrome. ${ }^{8}$ In addition, the lacrimal glands of $\mathrm{TSP} 1^{-1-}$ mice have altered acinar cell architecture; decreased cellular proliferation; increased IL1- $\beta$, IL-6, Th17, and interferon- $\gamma$ expression; altered stem cell transcription factor expression; and altered transcriptional signature of stem/ progenitor cells. ${ }^{11}$ These changes occur in a time-dependent manner such that changes were seen in mice as early as 4 weeks old and progressed as the animals aged. ${ }^{16,19}$ Because the mice used in the present study were 4 to 12 weeks old, disease was present. Thus, it is likely that the lacrimal glands of the diseased mice contained fewer healthy cells to isolate. After the cells were isolated, they were cultured for at least 14 days to let the acinar cells die and to ensure that only MECs were present before performing our experiments. This procedure has the advantage of obtaining enough MECs but the disadvantage of being time-consuming. In addition, in longtime culture periods, cells could undergo phenotypical changes, although it was not observed in our cultures. We postulated that studying MEC gene expression at an early disease stage might reveal important gene markers involved in triggering dry eye disease development, and, indeed, the microarray analysis found interesting differences between $\mathrm{TSP}^{-1-}$ and WT lacrimal gland MECs. The up-regulation of IL-6 (a cytokine frequently associated with dry eye disease $^{24,25}$ ) and of different inflammation signaling pathways points to an important effect of inflammation on MEC function. Surprisingly, the inflammasome pathway was down-regulated. In addition, the gene up-regulation of several extracellular matrix components in MECs from $\mathrm{TSP}^{-1-}$ mice lacrimal gland suggests the presence of a thicker extracellular matrix that may impede a proper contraction of the MECs. Further analysis of all these findings is warranted to determine its effect on MEC function.

In summary, MECs cultured from lacrimal glands respond to parasympathetic and sympathetic neurotransmitters as well as to purinergic agonists and high potassium chloride with an increase in intracellular $\left[\mathrm{Ca}^{2+}\right]$ and contraction. The responses of MECs cultured from TSP1 ${ }^{-1-}$ mice were altered; intracellular $\mathrm{Ca}^{2+}$ signaling and contraction regulated by cholinergic agonists (contraction), VIP $\left(\mathrm{Ca}^{2+}\right)$, and purinergic receptors (both functions) are decreased in TSP1 ${ }^{-I-}$ compared with WT mice. The lacrimal glands from $\mathrm{TSP} 1^{-1-}$ mice have fewer nerves than lacrimal glands ${ }^{19}$ from WT mice, and MECs from $\mathrm{TSP} 1^{-1-}$ mice have a decreased amount of contraction and the intracellular $\mathrm{Ca}^{2+}$ stores are smaller, so these MECs are able to respond less strongly than MECs from WT mice. Thus, we conclude that these findings can contribute to the aqueous deficiency found in dry eye disease, suggesting a crucial role of lacrimal gland MECs in the onset of dry eye.

\section{Acknowledgment}

We thank Dr. Ivo Kalajzic (University of Connecticut) and Dr. Sharmila Masli (Boston University) for kindly providing the $\alpha$-SMA-GFP and $\mathrm{TSP}^{-/-}$mice, respectively.

\section{Author Contributions}

L.G.-P. performed experiments and wrote the manuscript; R.R.H. and V.D. performed experiments; T.P.U. analyzed data; O.K.O. performed experiments and analyzed data; H.P.M. and D.A.D. conceived experiments and wrote the manuscript.

\section{Supplemental Data}

Supplemental material for this article can be found at http://doi.org/10.1016/j.ajpath.2020.06.013.

\section{References}

1. Dartt DA: Neural regulation of lacrimal gland secretory processes: relevance in dry eye diseases. Prog Retin Eye Res 2009, 28:155-177

2. Hodges RR, Vrouvlianis J, Scott R, Dartt DA: Identification of P2X(3) and $\mathrm{P} 2 \mathrm{X}(7)$ purinergic receptors activated by ATP in rat lacrimal gland. Invest Ophthalmol Vis Sci 2011, 52:3254-3263

3. Ohtomo K, Shatos MA, Vrouvlianis J, Li D, Hodges RR, Dartt DA: Increase of intracellular $\mathrm{Ca} 2+$ by purinergic receptors in cultured rat lacrimal gland myoepithelial cells. Invest Ophthalmol Vis Sci 2011, 52:9503-9515

4. Hodges RR, Dartt DA: Signaling pathways of purinergic receptors and their interactions with cholinergic and adrenergic pathways in the lacrimal gland. J Ocul Pharmacol Ther 2016, 32:490-497

5. Makarenkova HP, Dartt DA: Myoepithelial cells: their origin and function in lacrimal gland morphogenesis, homeostasis, and repair. Curr Mol Biol Rep 2015, 1:115-123

6. Lemullois M, Rossignol B, Mauduit P: Immunolocalization of myoepithelial cells in isolated acini of rat exorbital lacrimal gland: cellular distribution of muscarinic receptors. Biol Cell 1996, 86:175-181

7. Chitturi RT, Veeravarmal V, Nirmal RM, Reddy BV: Myoepithelial cells (MEC) of the salivary glands in health and tumours. J Clin Diagn Res 2015, 9:ZE14-ZE18

8. Gudjonsson T, Adriance MC, Sternlicht MD, Petersen OW, Bissell MJ: Myoepithelial cells: their origin and function in breast morphogenesis and neoplasia. J Mammary Gland Biol Neoplasia 2005 , $10: 261-272$

9. Haaksma CJ, Schwartz RJ, Tomasek JJ: Myoepithelial cell contraction and milk ejection are impaired in mammary glands of mice lacking smooth muscle alpha-actin. Biol Reprod 2011, 85:13-21

10. Weymouth N, Shi Z, Rockey DC: Smooth muscle alpha actin is specifically required for the maintenance of lactation. Dev Biol 2012, 363:1-14 
11. Shatos MA, Hodges RR, Morinaga M, McNay DE, Islam R, Bhattacharya S, Li D, Turpie B, Makarenkova HP, Masli S, Utheim TP, Dartt DA: Alteration in cellular turnover and progenitor cell population in lacrimal glands from thrombospondin 1(-/-) mice, a model of dry eye. Exp Eye Res 2016, 153:27-41

12. Shatos MA, Haugaard-Kedstrom L, Hodges RR, Dartt DA: Isolation and characterization of progenitor cells in uninjured, adult rat lacrimal gland. Invest Ophthalmol Vis Sci 2012, 53: 2749-2759

13. Hawley D, Tang X, Zyrianova T, Shah M, Janga S, Letourneau A, Schicht M, Paulsen F, Hamm-Alvarez S, Makarenkova HP, Zoukhri D: Myoepithelial cell-driven acini contraction in response to oxytocin receptor stimulation is impaired in lacrimal glands of Sjogren's syndrome animal models. Sci Rep 2018, 8:9919

14. Satoh Y, Sano K, Habara Y, Kanno T: Effects of carbachol and catecholamines on ultrastructure and intracellular calcium-ion dynamics of acinar and myoepithelial cells of lacrimal glands. Cell Tissue Res 1997, 289:473-485

15. Hodges RR, Zoukhri D, Sergheraert C, Zieske JD, Dartt DA: Identification of vasoactive intestinal peptide receptor subtypes in the lacrimal gland and their signal-transducing components. Invest Ophthalmol Vis Sci 1997, 38:610-619

16. Contreras-Ruiz L, Ryan DS, Sia RK, Bower KS, Dartt DA, Masli S: Polymorphism in THBS1 gene is associated with post-refractive surgery chronic ocular surface inflammation. Ophthalmology 2014, 121 : 1389-1397
17. Tatematsu Y, Khan Q, Blanco T, Bair JA, Hodges RR, Masli S, Dartt DA: Thrombospondin-1 Is necessary for the development and repair of corneal nerves. Int J Mol Sci 2018, 19:3191

18. Belmonte C, Nichols JJ, Cox SM, Brock JA, Begley CG, Bereiter DA, Dartt DA, Galor A, Hamrah P, Ivanusic JJ, Jacobs DS, McNamara NA, Rosenblatt MI, Stapleton F, Wolffsohn JS: TFOS DEWS II pain and sensation report. Ocul Surf 2017, 15:404-437

19. Bhattacharya S, Garcia-Posadas L, Hodges RR, Makarenkova HP, Masli S, Dartt DA: Alteration in nerves and neurotransmitter stimulation of lacrimal gland secretion in the TSP-1(-/-) mouse model of aqueous deficiency dry eye. Mucosal Immunol 2018, 11:1138-1148

20. Turpie B, Yoshimura T, Gulati A, Rios JD, Dartt DA, Masli S: Sjogren's syndrome-like ocular surface disease in thrombospondin-1 deficient mice. Am J Pathol 2009, 175:1136-1147

21. Kuony A, Michon F: Epithelial markers aSMA, Krt14, and Krt19 unveil elements of murine lacrimal gland morphogenesis and maturation. Front Physiol 2017, 8:739

22. Kuo IY, Ehrlich BE: Signaling in muscle contraction. Cold Spring Harb Perspect Biol 2015, 7:a006023

23. Burnstock G: Physiology and pathophysiology of purinergic neurotransmission. Physiol Rev 2007, 87:659-797

24. Massingale ML, Li X, Vallabhajosyula M, Chen D, Wei Y, Asbell PA: Analysis of inflammatory cytokines in the tears of dry eye patients. Cornea 2009, 28:1023-1027

25. Higuchi A, Kawakita T, Tsubota K: IL-6 induction in desiccated corneal epithelium in vitro and in vivo. Mol Vis 2011, 17:2400-2406 